\title{
Future European Parliament Elections: Ten Steps Towards Uniform Procedures
}

\author{
by Kai-Friederike Oelbermann and Friedrich Pukelsheim
}

Ten procedural steps for the European Parliament elections are proposed so as to achieve more uniformity among the national electoral provisions of the 27 Member States. The steps include the creation of a European Electoral Authority, the enhancement of the European party system, and the consolidation of the many diverse seat apportionment methods into the single divisor method with standard rounding (Webster/SainteLaguë). The introduction of semi-open list systems is addressed, as is the formation of a single European constituency for the election of an additional 25 MEPs. In the long run, the translation of votes into seats could be carried out using the biproportional variant of the divisor method with standard rounding, in order to better mirror the structure of the European Union.

Zehn Verfahrensschritte für die Wahlen zum Europäischen Parlament werden vorgeschlagen, um die in den 27 Mitgliedstaaten geltenden nationalen Regelungen weiter zu vereinheitlichen. Die Schritte umfassen die Schaffung einer europäischen Wahlbehörde, die Stärkung des europäischen Parteiensystems und die Beschränkung der vielen unterschiedlichen Sitzzuteilungsmethoden auf eine einheitliche: das Divisorverfahren mit Standardrundung (Webster/Sainte-Laguë). Die Einführung eines Wahlsystems mit halboffenen Listen wird ebenso diskutiert wie die Bildung eines europaweiten Wahlkreises für die Besetzung von 25 zusätzlichen Sitzen. Langfristig könnte eine europaweite Umrechnung von Stimmen in Sitze über die doppeltproportionale Variante des Divisorverfahrens mit Standardrundung vollzogen werden, um die Struktur der Europäischen Union besser abzubilden.

\section{Introduction}

Assessing the post-war European integration process, Wirsching illuminates the contraposition of Wille und Vorstellung. ${ }^{1}$ The antagonisms that went along with the process are reflected by the enigmatic character of the European Parliament (EP) and its predecessor, the Common Assembly. Among the institutions of the European Union, the EP is the one veering most between Sein und Schein. With

1 Wirsching, A.: Europa als Wille und Vorstellung - Die Geschichte der europäischen Integration zwischen nationalem Interesse und großer Erzählung, in: ZSE, 4 (2006), 488-506. 
a view towards the poor coverage of European issues in the campaign for the 2009 EP elections and the low voter turnout, Huber proposes a strengthening of the political parties at the Union level to further develop the legitimising powers of the EP. ${ }^{2}$

The OSCE/ODIHR report describes the 2009 elections to be "essentially 27 separate national elections to a supra-national body ... characterised by a considerable diversity of national rules, procedures, and practices". ${ }^{3}$ The report predicts that "the debate about the EP's electoral framework is likely to continue during the next legislature". Indeed, the EP is determined to deal with the issue. Its Committee on Constitutional Affairs has appointed Andrew Duff (MEP) as rapporteur on this initiative. An explanatory statement was issued in April 2010, ${ }^{4}$ and a draft report in July $2010 .^{5}$

The elections to the EP are regulated in the 1976 Elections Act, as amended in 2002. Duff reviews its history to date. ${ }^{6}$ We quote the consolidated version appended as Annex II to the draft report, and refer to it as the "EA". The OSCE/ODIHR and Duff reports offer a great many suggestions for the amendment of the EA.

This paper, however, specifically aims at raising the level of uniformity among the 27 national electoral provisions, leaving aside the problem of how the 751 seats are allocated to the 27 Member States. Section II seconds Duff in his plea to set up a European Electoral Authority. ${ }^{8}$ In Section III we suggest to give the European parties a functional role in the elections. As proposed by Schleicher, ballot sheets should show the names of the European parties and the electoral threshold should refer to how European parties perform at Union level. ${ }^{9}$

2 Huber, P.M.: Demokratische Legitimation in der Europäischen Union, in: ZSE, 7 (2009), 364-380.

3 OSCE Office for Democratic Institutions and Human Rights, Elections to the European Parliament 4-7 June 2009, Expert Group Report, Warsaw, 22 September 2009.

4 Duff, A.: Explanatory statement (20.04.2010). Proposal for a modification of the Act concerning the election of the members of the European Parliament by direct universal suffrage of 20 September 1976, European Parliament, Committee on Constitutional Affairs, 2010.

5 Duff, A.: Draft report (05.07.2010) on a proposal for a modification of the Act concerning the election of the members of the European Parliament by direct universal suffrage of 20 September 1976, European Parliament, Committee on Constitutional Affairs, 2010.

6 Duff, A., Explanatory statement, op. cit.

7 Duff, A., Draft report, op. cit.

8 Duff, A., Explanatory statement, op. cit.

9 Schleicher, D.: What if Europe held an election and no one cared?, in: Harvard International Law Journal, 52 (2011), 109-161. 
Section IV distinguishes between the establishment of multiple constituencies, and the subdivision of an electoral area into several districts. The terms constituency and district are interpreted in the distinct sense of Oelbermann/Palomares/Pukelsheim, henceforth referred to as $O P P .{ }^{10}$ Section $\mathrm{V}$ sets the stage to advance the uniformity level of the electoral procedures. We replace the (nonvisible) European parties by the (visible) Political Groups in the EP. For the translation of vote counts into seat numbers we solely employ the divisor method with standard rounding (Webster/Sainte-Laguë). With these prerequisites, Section VI presents a prototype evaluation of the 2009 EP elections.

Sections VII and VIII address two specific proposals from Duff, the introduction of a semi-open list system, and the creation of a single European constituency. ${ }^{11}$ In the light of our prototype evaluation of the 2009 elections we conclude that both proposals call for further specification before their prospective merits can be assessed. Section IX points out that the biproportional variant of the divisor method with standard rounding would conform particularly well with the constitutional character of the European Union. Section X enumerates ten steps which, in the light of this article, seem to be called for to move the EA in the direction of more uniformity.

Article 223 TFEU calls upon the EP to draw up a proposal for the election of its Members in accordance with "a uniform procedure" or in accordance with "principles common to all Member States". The ten steps do not suffice to define "a uniform procedure" in the singular. They aim to increase the degree of uniformity among the plurality of procedures used by the Member States, and to carry the "principles common to all Member States" to a level enabling a unionwide view of future EP elections.

\section{European Electoral Authority}

The biggest obstacle to progress is ignorance. When compiling the $2009 \mathrm{EP}$ elections overview in $O P P$, we found that the national provisions governing the elections in the Member States are widely dispersed and hard to get hold of. Authoritative facts on the elections are not even available on the EP websites. The information offered is incomplete, nor is it evident whether it is truly reli-

10 Oelbermann, K.-F./Palomares, A./Pukelsheim, F.: The 2009 European Parliament elections: From votes to seats in 27 ways, Evropská volební studia-European Electoral Studies, 5 (2010), 148-182.

11 Duff, A., Draft report, op. cit. 
able. We get the impression that Parliament itself lacks a firm knowledge of how it is elected, and how seats are allocated. After all, the European Union admits 23 official languages and operates with three alphabets, Latin, Greek, and Cyrillic. Some Member States make their national provisions accessible in their mother tongues only. Others provide unofficial translations into English, occasionally with an irritating lack of proficiency when it comes to describing the calculations of converting votes into seats. The OSCE/ODIHR report is flawed by factual errors, as is the survey of the national electoral provisions provided by Lehmann, ${ }^{12}$ and the annex on current electoral practices in Member States in Duff. ${ }^{13}$ In all likelihood, so is the overview in $O P P$.

In Duff's list of amendments, a prominent item is the creation of a European Electoral Authority. ${ }^{14}$ We suggest that such an office should also serve as a center for documentation. The EP will soon lose its memory on how it was elected in previous legislative periods unless legal acts are archived in a central office. Member States ought to be obliged to deposit their electoral provisions with the Electoral Authority. As it is equally laborious and challenging to locate final vote counts, Member States should also be obliged to deposit their final vote counts with the Electoral Authority.

\section{European Party System}

Another obstacle for a move towards more uniformity is the lack of visibility of the European party system. This is not to say that European parties do not exist. In 2009 nine of them cashed in more than ten million euros from the Union's general budget. ${ }^{15}$ However, European parties seem to function like astronomical black holes. They absorb the money without emanating any political messages. In order to enhance their visibility, Schleicher puts forward two proposals: ${ }^{16}$ to print the names of the European parties visibly on ballot sheets and to introduce a threshold directly aiming at their electoral performance. Before discussing this in greater detail, however, we need to be more explicit on what we mean by the term European party.

12 Duff, A., Explanatory statement, op. cit.

13 Lehmann, W.: The European elections: EU legislation, national provisions and civic participation, European Parliament Directorate-General for Internal Policies, Policy Department C, Brussels, 2009.

14 Duff, A., Draft report, op. cit.

15 Cf. Party Subventions for 2009, www.europarl.europa.eu.

16 Schleicher, D., op. cit. 
There already exists a precise definition of the term political parties at European level. ${ }^{17}$ In essence, for a party to qualify accordingly, it must already be firmly established in the EP or in national or regional parliaments of at least one quarter of the Member States. This requirement may be too restrictive for newcomers to join upcoming EP elections. Therefore, we widen the meaning of European parties to include, in addition, political organisations at European level that observe the principles on which the European Union is founded and that campaign in the prospective EP elections in at least a quarter of the Member States. European parties, in the wide sense, can be expected to contribute to shaping European awareness and to express the will of citizens of the Union, as demanded by Article 10 IV TEU. With this wider meaning of European parties in mind, we return to the discussion of the Schleicher plan.

Firstly, European parties should be given a place on the ballot sheets. Current ballot design is such that domestic parties are listed without indicating any affiliation with a European party. The Schleicher plan assumes that a domestic party seeks membership with a European party and that the affiliation is prominently exhibited on the ballot sheets by printing the emblem and the name of the European party ahead of the name of the domestic party. This would provide at least some clue for voters to see a European perspective when casting their votes. It would be a step in the direction of overcoming the current situation where the information on the ballot sheets is restricted to the domestic sphere.

Secondly, the Schleicher plan proposes an electoral threshold at the level of European parties, by requiring them to attract at least three percent of valid votes in each of at least a quarter of Member States. For the sake of brevity we refer to this stipulation as the 3-in-7 threshold. When a European party passes the 3-in-7 threshold, all votes cast for the party anywhere in the 27 Member States become effective and enter into the seat apportionment calculations. A European party passing the 3-in-7 threshold automatically qualifies as a political party at European level according to the Union's regulation.

Schleicher accepts further thresholds in national electoral provisions, in addition to the 3-in-7 threshold. We feel that multiple layers of thresholds are too confusing. After all, in 2009 the handling of thresholds turned out to be quite diverse, cf. OPP. A single 3-in-7 threshold would cut back on this creative threshold 
diversity. We would rather bar additional domestic thresholds and make do with the 3-in-7 threshold.

\section{Electoral Regions, Areas, Constituencies, and Districts}

In electoral systems, the terms region, area, constituency, and district are not standardised. For EP elections we define their meanings as follows: the electoral region comprises all of the European Union. Since the organisation and the evaluation of the elections are particular to each Member State, we take a Member State to function as an electoral area. According to Article 2 EA it is up to each Member State whether to establish multiple constituencies or whether to subdivide its electoral area in a different manner.

We give the establishment of constituencies the following meaning: in the presence of constituencies, the seat contingent of a Member State is apportioned among constituencies prior to the election as stipulated in the national electoral provisions. Constituencies are established in the United Kingdom (12 constituencies), Ireland (4), France (8), and Belgium (3). For instance, in Belgium the three constituencies are formed by the French, Dutch, and German-speaking parts of the country. The establishment of constituencies is a bottom-up approach, in that the geographical entities are joined to form the electoral area.

The subdivision into districts appears as a top-down approach. Districts, too, are subareas, but the electoral system handles them differently. Firstly, every party is allocated a statewide seat number in proportion to its statewide vote counts. Secondly, for each party a subapportionment calculation is carried out allocating the party's statewide seats among its district lists, again in proportion to vote counts. Three Member States make use of a subdivision into districts, Germany (16 districts), Italy (5), and Poland (13).

The number of seats available in a constituency is called the constituency magnitude. The number of seats allocated to a district is called the district magnitude. The two concepts differ in that constituency magnitudes are prespecified ex ante, while district magnitudes emerge ex post.

Our distinction between the establishment of multiple constituencies and the subdivision into several districts is not generally shared in the literature. Article 2 EA reads as follows:

In accordance with its specific national situation, each Member State may establish constituencies for elections to the EP or subdivide its electoral area in a different manner, without generally affecting the proportional nature of the voting system. 
Duff breaks Article 2 into three clauses that merely refer to the term 'constituencies' and omit any reference to a subdivision in a different manner: ${ }^{18}$

1. Each Member State may establish constituencies for elections to the EP on a territorial basis.

2. States with a population of at least twenty million shall subdivide their electoral area into a number of regional constituencies.

3. The establishment of constituencies must not generally affect the proportional nature of the voting system.

There is no indication as to whether the focus on the establishment of constituencies and the omission of a subdivision in a different manner are intentional. Is it meant to restrict the margin of discretion which Member States enjoy under the auspices of the common principles of the EA? The second phrase forces the seven largest Member States to subdivide their electoral area into constituencies. While Germany is composed of federal states, its Grundgesetz embodies a rather unitary character. It would seem to us that the second phrase forces Germany to rewrite its Basic Law. In Member States such as Spain, the establishment of constituencies might constitute a Herculean task.

The third phrase sounds innocuous, but may give rise to intriguing questions. We illustrate its consequences by referring to the Member States that in 2009 made use of the establishment of constituencies (Belgium, France, Ireland, and United Kingdom). In Belgium, the Deutschsprachiges Wahlkollegium constituency has a single seat available for apportionment. As one seat is not enough to achieve any proportionality whatsoever, the third phrase is violated. Evidently, the constituency is established for reasons of minority representation. However, exceptions in favor of minority representation are not included in Duff's amendment. In France, the Outre-Mer constituency commands just three seats. In this case, it is not minority representation that is decisive, but the particularities of the territorial structure of the constituency.

The other constituencies are void of minority considerations or geographical peculiarities. Nevertheless, the French Massive Central/Centre constituency commands only five seats, all Irish constituencies and the British North-East constituency are allocated a mere three seats. Not much proportionality can be achieved with such a small number of seats, raising the question why voters in these constituencies are deprived of their right to proportional representation. 
As for the EP's composition, we can observe a lively debate in Parliament on the rule that Member States must be allocated at least six seats in order to represent the diversity of their political spectrum. When Member States make use of their margin of discretion, they draft constituencies sufficiently small that there is no hope of representing the political spectrum. We propose to rephrase the amendment in a more confirmatory manner: 3. The establishment of constituencies must be such that there are at least six seats available for proportional representation, unless sufficient reason justifies a smaller constituency magnitude.

Even a constituency magnitude of six seats entails severe limitations on the attainable level of proportional representation. The problem lies in the range of vote shares needed to obtain representation in Parliament. This range begins with the threshold of representation and ends with the threshold of exclusion. ${ }^{19}$ Below the threshold of representation, it is impossible for a party to win a seat. Above the threshold of exclusion, a party is guaranteed a seat. Between these two thresholds, the likelihood of winning a seat varies depending on how the other parties perform. With only a few seats available, the effective threshold is set far above five percent of the valid votes.

In the following, we rely on the divisor method with standard rounding (Webster/Sainte-Laguë). For this method, with six seats available and four parties campaigning, the threshold of representation amounts to $1 / 14=7$ percent, while the threshold of exclusion is $1 / 10=10$ percent. Hence, with a vote share below seven percent, representation is plainly impossible. A party needs at least ten percent voter support to be certain to gain a seat. A threshold of ten percent defies the current five percent threshold in Article 3 EA. Moreover, it is viewed rather critically by the European Court of Human Rights. ${ }^{20}$

With a constituency magnitude of twelve seats and six parties campaigning, the threshold of representation falls to $1 / 28=4$ percent. The threshold of exclusion amounts to $1 / 20=5$ percent. In 2009 all Member States, except the six smallest, had twelve or more seats at their disposal. These Member States should be invited to establish constituencies with magnitude twelve or more, so that the threshold of exclusion does not become overly large.

19 Gallagher, M./Mitchell, P.: The Politics of Electoral Systems, Oxford, 2008, 607.

20 European Court of Human Rights, Yumak and Sadak versus Turkey, No. 10226/03, Judgment by the Grand Chamber of 8 July 2008. 


\section{Hypothetical Uniformity}

The Schleicher plan cannot be applied directly to the $O P P$ data because roughly 20 domestic parties in the EP are not affiliated with any European party. For the purpose of a hypothetical uniform evaluation, we identify the affiliation of domestic parties to Political Groups in the EP, as do Rose/Bernhagen. ${ }^{21}$ We are aware that Political Groups in the EP are not identical to, nor exchangeable with, European parties. Yet, the simulation is instructive to clarify the roles of domestic parties and of European parties.

At the beginning of the 2009-2014 legislative period, there were seven Political Groups in the EP, complemented by an eighth 'pseudo-group', NA, consisting of the MEPs not attached to any of the seven proper Political Groups:

Table 4: Political Groups in the European Parliament (2009-2014)

\begin{tabular}{l|l|c}
\hline Acronym & Political Group in the EP & Seats \\
\hline EPP & European People's Party & 265 \\
\hline S\&D & Progressive Alliance of Socialists and Democrats & 184 \\
\hline ALDE & Alliance of Liberals and Democrats for Europe & 84 \\
\hline Greens/EFA & European Greens / European Free Alliance & 55 \\
\hline ECR & European Conservatives and Reformists & 54 \\
\hline GUE/NGL & European United Left / Nordic Green Left & 35 \\
\hline EFD & Europe of Freedom and Democracy & 32 \\
\hline NA & Non-attached MEPs & 27 \\
\hline Total & & 736 \\
\hline
\end{tabular}

Source: European Parliament, 2009.

In $O P P$, we list the names of the domestic parties and, separated by a colon, the name of the Political Group to which each party is affiliated. All of the eight Political Groups passes the 3-in-7 threshold. Hence, their votes enter into the apportionment processes in all Member States where they campaign. The eight Political Groups and the votes they drew provide the database for the unionwide evaluation in Table 2.

Two kinds of problems come to light. Firstly, in Slovakia, three domestic parties are affiliated with the Political Group EPP. From a Union viewpoint, the EPP

21 Rose, R./Bernhagen, P.: Inequality in the representation of citizens in the European Parliament, University of Aberdeen, Centre for the Study of Public Policy, Studies in Public Policy 472, 2010. 
submits three lists of candidates to the Slovak electorate. There are more instances where two or more domestic parties merge their MEPs into the same Political Group. In most countries, proportional representation systems do not admit parties to campaign with two or more lists because this would secure an undue advantage over their competitors. The EA should demand that domestic parties belonging to the same European party submit a single, joint list within each constituency and within each district.

Secondly, the 2009 elections feature another complication. Two or more parties registered an alliance (also known as list apparentement), yet the MEPs so elected join different Political Groups. For instance, in Denmark, Alliance 1 consists of three parties. The four MEPs of the first party join S\&D, the two MEPs of the second party go along with Greens/EFA, and the third party sends no MEP into the EP. So what does it mean when a citizen casts a vote for a partner of Alliance 1? Is the vote going to help the party of the voter's choice to win a seat, or another partner of the alliance, or does it fail to account for a seat? This disorientation deprives voters of their right to a direct election. We therefore chose to exclude party alliances from EP elections. In fact, party alliances become superfluous as soon as a size-neutral seat apportionment method is adopted.

Democratic representation usually builds on the principle of equal elections, as captured by the motto one person, one vote. In handling this principle, the European Union proves to be a political body sui generis, torn between degressivity, progressivity, and proportionality. Degressive representation prevails for the composition of the EP, the allocation of the 751 seats to the 27 Member States. Degressivity means that a human being's electoral weight decreases when seen as a citizen of larger Member States and increases for citizens of smaller Member States. On the other hand, progressive representation is based on viewing the same individuals as voters of political parties. Progressivity thus means that a human being's electoral weight increases for citizens who vote for larger parties and decreases for voters of smaller parties. The seat apportionment method manifestly serving progressivity is the divisor method with rounding down (Jefferson/D'Hondt/Hagenbach-Bischoff), employed in 16 of the 27 Member States in 2009. We believe that degressive representation and progressive representation contradict the principle of proportional representation.

The seat apportionment method harmonising most convincingly with the one person, one vote principle is indeed the divisor method with standard rounding (Webster/Sainte-Laguë). This is the central message of the seminal monograph 
of Balinski/Young, who corroborate their findings with a plethora of arguments. ${ }^{22}$ In particular, the method is neutral towards electoral success. Whether larger or smaller in terms of vote counts, every party gets on average as many seats as it deserves on the grounds of the theoretical Rule of Three. There is absolutely no incentive for parties to manipulate the system by registering as alliances.

Furthermore, the divisor method with standard rounding is based on the most transparent calculations. Each vote count is divided by a common divisor and the resulting quotient is rounded to the nearest whole number, which then constitutes the seat contingent. The divisor plays the role of an electoral key specifying the number of voters accounting for "about" one seat (that is, before rounding).

\section{Prototype Evaluation of the 2009 EP Elections}

The unified evaluation of the 2009 EP elections revolves around Table 2 and is complemented by Tables 3 and 4 . The essential items are the pairs of numbers in two adjacent columns (Table 2) or separated by a hyphen (Tables 3 and 4). On the left-hand side, we print the vote counts of a Political Group and on to the right the seat numbers hypothetically apportioned to the Group by the divisor method with standard rounding (Webster/Sainte-Laguë).

Table 2 calls for a series of comments. Member States are sorted by population figures from large to small. The reverse ordering from small to large would be equally informative. The OSCE/ODIHR report lists Member States in protocol order. This injects a considerable amount of randomness and disguises the effects of size. The two-letter code of a Member State is followed by a slash (/) when the State subdivides its electoral area into several districts (Germany, Italy, Poland). A star (*) indicates that the State establishes multiple constituencies (France, United Kingdom, Belgium, Ireland). Population figures are taken from the Official Journal, which publishes these figures for qualified majorities in the Union's Council of Ministers. ${ }^{23}$ Since the rationale for referring the Council of Ministers' qualified majority decisions to population is concurrent with the rationale for basing representation in the EP on the Union's citizens, we believe that in both cases the same figures should be used. Strangely, the Official Journal rounds population figures into multiples of centuries of a hundred citizens and

22 Balinski, M./Young, H.P.: Fair Representation - Meeting the Ideal of One Man, One Vote, Second Edition, Washington DC, 2001.

23 Official Journal of the European Union, L 325 (11.12.2009), 55-56. 
prints them as decimal fractions of legions of a thousand citizens. Since Eurostat takes pains not to round whole citizens into numerical fractions, we prefer the authentic Eurostat input to the manipulated Official Journal output. The "Seats" column lists the seat contingents in force for the 2009 elections to allocate the 736 seats among the 27 Member States.

The Political Groups' vote counts are aggregated from OPP. All party alliances are included. Non-attached parties and non-attached independent candidates not winning a seat are dismissed. In Spain, Italy, the Netherlands, the United Kingdom, and Latvia, some domestic parties are represented by MEPs who joined different Political Groups. In these cases, we redistributed votes in proportion to how many MEPs joined which Group. In Luxembourg, voters can mark up to six votes on their ballots. During the 2009 elections, the average number of marks per ballot was $A=1121305 / 198364 \approx 5.7$. Therefore, we divide the vote counts from Luxembourg by $A$ and round the results to the nearest whole number. In this way, we obtain pseudo vote counts referring to individuals, not to ballot sheet marks. In Ireland, Malta, and the Northern Ireland constituency of the United Kingdom, where single transferable vote systems are used, only first preferences are entered in Table 2. The last column quotes state divisors belonging to the divisor method with standard rounding (Webster/Sainte-Laguë). For each Member State, the divisor signifies the number of voters justifying about one seat. If degressive proportionality were a concept of intrinsic value, divisors would be decreasing so that fewer voters suffice to account for about one seat as Member States become smaller. This is not the case. Due to varying voter turnouts, divisors jump back and forth, only roughly in line with population figures.

The overall conclusion is rather encouraging. The hypothetically calculated seat numbers in Table 2 most often coincide with the actually apportioned seat numbers in $O P P$ or deviate by no more than one seat.

There are two exceptions, France and the United Kingdom. Both states establish several constituencies and then allocate seats by applying the divisor method with rounding down (Jefferson/D'Hondt/Hagenbach-Bischoff). The method is notorious for being biased, each application promising some bonus seat shares for larger parties at the expense of losses of smaller parties. When repeated often enough, bonus seats (and malus seats) materialise with near certainty. In fact, the largest party carries away a bonus of four seats both cases. This provides some confirmation for our decision to only use the divisor method with standard rounding (Webster/Sainte-Laguë). The latter method is neutral to size and immune against any biasing effects from establishing multiple constituencies. 
Germany, Italy, and Poland subdivide their electoral areas into several districts. The statewide seats of a Political Group from Table 2 need to be subapportioned among districts. As an illustration, the top part of Table 4 exhibits the calculations for Italy. Italy constitutes a particular challenge to the advancement of the EA. The challenge arises not only from a quantitative, procedural analysis, but also from the normative, judicial viewpoint. The Italian electoral provisions are self-contradictory. Is this solely an Italian issue? Could non-Italian Union citizens who vote in Italy feel impaired in their electoral rights and go to court? To which court?

The seat apportionment method used in Italy is a variant of the Hare quota method with residual fit by greatest remainders. With this method, district magnitudes in the $2009 \mathrm{EP}$ election come out to be $21,15,15,15$, and 6 , see OPP. However, Article 2 of the Italian electoral provisions pre-specifies the magnitudes in proportion to population. ${ }^{24}$ The law stipulates the district magnitudes to be $19,13,14,18$, and 8 . None of the districts is allocated the number of seats legally specified in Article 2. The pre-specification of the district magnitudes is at odds with the instructions on how votes get translated into seats. Pennisi/ Ricca/Simeone criticise the bachi e buchi in the Italian electoral systems, to no avail. $^{25}$ The bug persists. A solution to the problem is the biproportional apportionment method used in the Swiss Cantons of Zurich, Schaffhausen, and Aargau. ${ }^{26}$ Its application to the Italian data is displayed in the bottom part of Table 3.

24 Legge 24 gennaio 1979, n. 18-Elezione dei membri del Parlamento Europeo spettanti all'Italia (G.U. 30 gennaio 1979 n. 29), executed through Decreto del $1^{\circ}$ aprile 2009 (G.U. Serie generale 3 aprile 2009 n. 78).

25 Pennisi, A./Ricca, F./Simeone, B.: Bachi e buchi della legge elettorale italiana nell'allocazione biproporzionale di seggi, Sociologia e ricerca sociale, 79 (2006), 55-76; Pennisi, A./Ricca, F./Simeone, B.: Una legge elettorale sistematicamente erronea, Polena: Political and Electoral Navigations-Rivista Italiana di Analisi Elettorale, 6 (2009), 65-72.

26 Pukelsheim, F./Schuhmacher, C.: Das neue Zürcher Zuteilungsverfahren für Parlamentswahlen, Aktuelle Juristische Praxis-Pratique Juridique Actuelle, 5 (2004), 505-522; Balinski, M./Pukelsheim, F.: Matrices and politics, in: Liski, E./Isotalo, J./Puntanen, S./Styan, G.P.H. (ed.), Festschrift for Tarmo Pukkila on his 60th Birthday, Tampere, 2006, 233-242. 


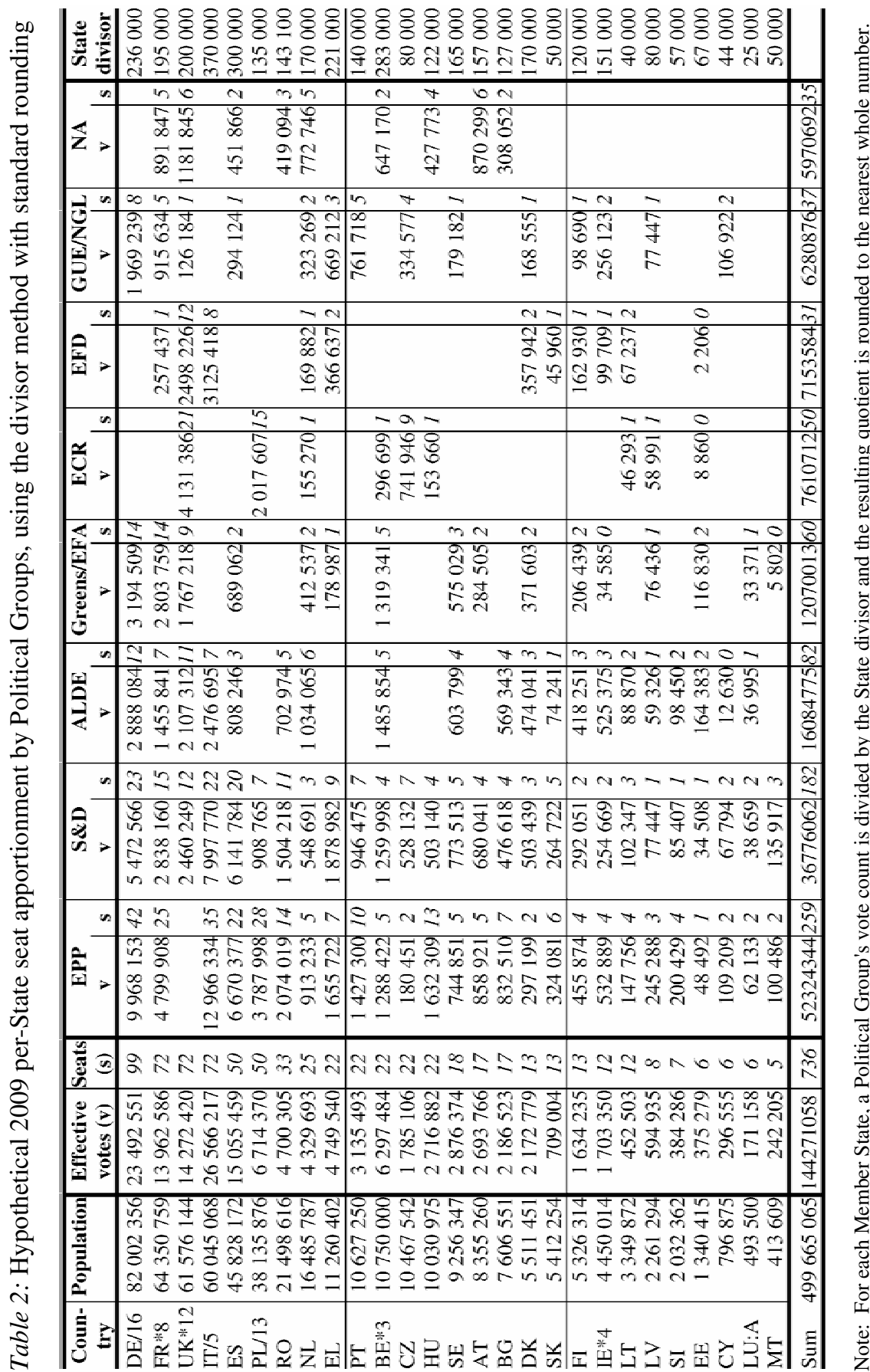




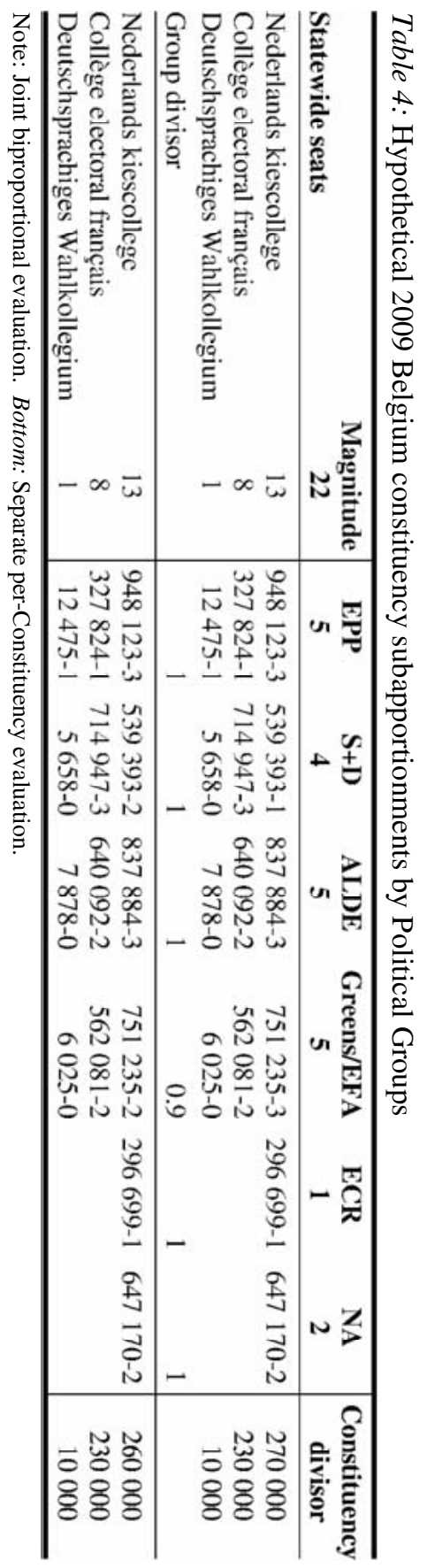

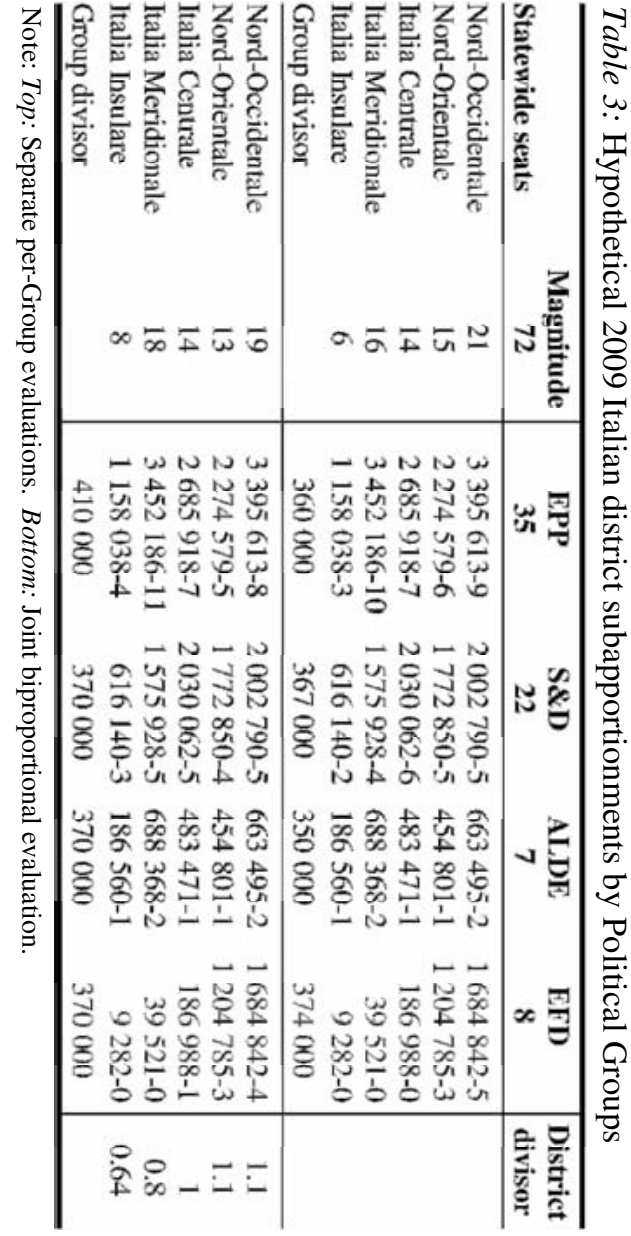


Furthermore, the biproportional solution provides a tool to fit France, United Kingdom, and Belgium into the hypothetical uniform evaluation in Table 2. Table 4 exemplifies the calculations for Belgium, the top part showing the novel joint biproportional evaluation, the bottom part current separate per-constituency evaluations. For the biproportional application, the vote count for a Political Group in a constituency is divided by two divisors, the constituency divisor and the group divisor. The resulting quotient is rounded to the nearest whole number. Constituency magnitudes and statewide Group seat numbers are met precisely. As before, the seat numbers obtained deviate from the actual allocation by at most a single seat transfer. France and the United Kingdom would call for similar tables. Since the biproportional evaluation meets the Groups' statewide seat numbers, the threshold of exclusion that becomes relevant originates from the Member State's seat contingent, not from constituency magnitudes. Small magnitudes no longer entail high thresholds of exclusion.

\section{Semi-open List Systems?}

Duff, in drawing conclusions, proposes "the compulsory use of the preferential semi-open list system" as if there were only one such system. ${ }^{27}$ Without describing in detail which semi-open list system he proposes, any discussion of its prospective merits remains speculative. The proposed introduction of a semi-open list system correlates with the proposition that Member States with a population of at least 20 million shall establish multiple constituencies. Presumably, ballot sheets are otherwise feared to reach poster size and become too unwieldy for voters to handle their semi-open choice efficiently.

In any case, if the EP desires to cap the size of constituencies, population figures are an inappropriate index to use. After all, the EP assigns degressive weights to batches of 20 million citizens consisting of Romanians, Poles, Spaniards, Italians, Englishmen, Frenchmen, and Germans. The index to refer to is constituency magnitude. Parliament may decree a largest constituency magnitude of 25 seats or the like, in addition to a smallest constituency magnitude of six seats.

27 Duff, A., Explanatory statement, op. cit. 


\section{A Unionwide Constituency for 25 Additional MEPs?}

Duff proposes to elect 25 additional MEPs from a single constituency formed by the entire Union territory, using semi-open lists. ${ }^{28}$ The goal is to enhance the European dimension of EP elections and to increase the representative capability of the EP. We wonder how the proposal would work out.

Assuming that prospective second votes for the unionwide lists run more or less in parallel to the (first) votes shown in Table 2, every batch of 5600000 votes accounts for about one of the 25 seats. The EPP would be awarded nine seats, S\&D seven, ALDE three, Greens/EFA two, and ECR, EFD, GUE/NGL and NA one each. Contemplating the EPP column of Table 2, the nine EPP seats go to Italy, Germany, Spain, France, Poland, Romania, Greece, Hungary, and Portugal. The allocation of the unionwide seats of the other Political Groups is similarly predictable. Altogether not much of an election is going on. Rather, 25 reliably safe EP tickets are dealt out among the larger Member States.

Duff remains silent on the origin of the additional 25 seats. ${ }^{29}$ If "additional" is taken literally, they are created in addition to the prospective 751 seats. The creation must appear a sheer nightmare to all believers in degressivity, since all of these seats will go to the larger Member States. Alternatively, the "additional" seats may be subtracted from the 751 total and diminish the contingents of the Member States of the successful candidates. In essence, the larger Member States would have to upgrade seats from the domestic to the Union level although they already face a reduced contingent due to degressivity.

Another imbalance may require attention: the twelve million EPP voters in Italy would be strong enough to carry two EP seats. A first option is to place two Italian candidates on the EPP list. We doubt whether the EPP partners would tolerate this much progressivity in favor of Italy. A second option would be an aggressive campaign by the Italian EPP branch on behalf of, for example, the Lithuanian candidate, so that sufficiently many Italian EPP voters use the semiopen lists to vote the Lithuanian candidate into Parliament, in addition to the one Italian candidate.

Thus, the idea of a unionwide constituency for the election of 25 additional MEPs would seem to require further contemplation. 


\section{Uniformity via Biproportionality?}

Advances in EP electoral matters hinge on the functioning of a European party system. Only when German voters of Angela Merkel's Christlich Demokratische Union acknowledge that their votes may be instrumental for a candidate of Silvio Berlusconi's Popolo della Libertà to win an EP seat can we safely aggregate votes on the Union level and evaluate them unionwide. Rather than limiting ourselves to the unionwide election of an extra 25 MEPs, we could allocate all 751 seats in a unionwide calculation. The biproportional parts of Tables 3 and 4 point the way how to respect Member States' seat contingents and parties' unionwide seat numbers simultaneously. From the computational viewpoint, 27 Member States and eight Political Groups are handled in the same fashion as are five districts and four Political Groups in Italy or three constituencies and six Political Groups in Belgium. Currently, however, acceptance of vote aggregation on the Union level remains Zukunftsmusik.

\section{Conclusion}

In the Council of Europe's Venice Commission, ${ }^{30}$ all 27 Member States confirm Europe's electoral heritage of conducting parliamentary elections by direct universal suffrage in a free, equal and secret ballot. Moreover, the Union intends to accede to the European Convention for the Protection of Human Rights and Fundamental Freedoms. ${ }^{31}$ Paying due attention to the principle of electoral equality would help rectifying misunderstandings concerning the EP's democratic legitimisation as voiced in the Lisbon decision of the German Federal Constitutional Court.

All elections entail the counting of votes. The final vote counting processes for the EP elections require synchronisation. With current election days ranging from Thursday to Sunday, a compromise median day appears to be a Saturday. At present, Saturday is a voting day in just five Member States: Italy, Czech Republic, Slovakia, Latvia, and Malta. ${ }^{32}$

30 Council of Europe, European Commission for Democracy through Law (Venice Commission), Code of good practice in electoral matters-Guidelines and explanatory report, Opinion no. 190/2002, CDL-AD (2002) 23 rev.

31 Article 6 II TEU, Official Journal of the European Union, C 83 (30.3.2010), 13-45, 19.

32 Duff, A., Explanatory statement, op. cit. 
When polling stations in Greece are kept open from 9 to 18 local time, in Italy from 8 through 17, and in Portugal from 7 to 16, they close at the same point in time. Vote counting would take place simultaneously on Saturday evening. National electoral offices might process the data on Sunday morning. The European Electoral Authority could issue preliminary final results Sunday afternoon, in time for the Monday newspapers.

In conclusion, we hold that the following ten steps would be helpful to move in the direction of more uniform procedures for EP elections.

1. A European Electoral Authority is created. Member States are invited to deposit their national electoral provisions and final electoral results with the Authority.

2. Ballot sheets must exhibit emblems and names of European parties ahead of affiliated domestic parties.

3. Domestic parties that belong to the same European party submit a joint list of candidates.

4. Alliances of European parties (also known as list apparentements) are not allowed.

5. Votes become effective (enter into the seat apportionment calculations) only (a) if cast for a European party attracting at least three percent of valid votes in each of at least a quarter of Member States, or (b) if cast for a domestic party that the Member State recognises as a minority representation party, or (c) if cast for an independent candidate who passes the threshold for independent candidates as stipulated by the Member States' national provisions.

6. Every Member State may establish multiple constituencies or subdivide its electoral area into several districts.

7. Each constituency must be large enough to provide for at least six seats, unless sufficient reason justifies a smaller constituency magnitude.

8. For list systems, the translation of votes into seats is based on the divisor method with standard rounding (Webster/Sainte-Laguë) or its biproportional variant.

9. The EP is elected by direct universal suffrage in a free, equal and secret ballot, as guaranteed in Articles 9 and 14 III TEU. Degressive proportionality is relegated to issues concerning the composition of the EP as in Article 14 II TEU.

10. Election day is a Saturday in May. Polling stations close at 16:00 GMT. 
There is a long-lasting lamento that the EP elections are second-order elections, ever since Reif/Schmitt coined the phrase. ${ }^{33}$ The above ten steps are proposed with the intention of providing a procedural frame for the EP elections to raise to first-order. The ten steps, or the amendments of Duff, ${ }^{34}$ or the changes suggested by Hix/Hagemann, ${ }^{35}$ or a mixture thereof, may help to strengthen the legitimising powers of the EP, to improve the connection between the MEPs and their electorates, and to raise voter turnout above the 2009 all-time low.

33 Reif, K./Schmitt, H.: Nine second-order national elections-A conceptual framework for the analysis of European election results, European Journal of Political Research, 8 (1980), 3-44.

34 Duff, A., Explanatory statement, op. cit.

35 Hix, S./Hagemann, S.: Could changing the electoral rules fix European Parliament elections?, Politique européenne, 28 (2009), 27-41. 